\title{
Penghapusan diskriminasi, ras, dan etnis pembuatan surat keterangan waris yang didasarkan pada penggolongan penduduk
}

\section{Fadilla Dwi Lailawati}

Fadilla Dwi Lailawati; Fakultas Hukum Universitas Merdeka Malang; Jl. Terusan Dieng No. 62-64; Malang 65115; Jawa Timur; Indonesia.

\section{A R T I CLEINFO}

\section{Article history:}

Received 2020-01-02

Received in revised form

2020-02-18

Accepted 2020-04-01

\section{Kata kunci:}

Hukum Waris; Penggolongan

Penduduk; Surat Keterangan

Waris.

\section{Keywords:}

Inheritance Law; Classification of Population; Certificate of

Inheritance.

DOI: https://doi.org/10.26905/

idjch.v11i1.4051.

How to cite item:

Lailawati, FD. (2020). Penghapusan diskriminasi, ras, dan etnis pembuatan surat keterangan. Jurnal Cakrawala Hukum, 11(1), 1220. doi:10.26905/idjch.v11i1.4051.

\section{Abstrak}

Hukum waris tidak terlepas dari asal muasal bangsa indonesia yang terdiri dari beragam suku atau etnis, sehingga adanya beragam aturan yang telah terbentuk terkait hukum waris di Indonesia.Golongan penduduk serta hukum yang berlakuu guna setiap golongan tersebut berdasarkan pada ketentuan 163 ayat (1) IS (Indische staats Regeling) warisan dari Pemerintah Kolonial Hindia Belanda. golongan penduduk serta hukum yang ada guna tiap - tiap golongan penduduk iitu ialah Politik Hukum yang dari pemerintah kolonial guna mengawasii penduduk berada didaerah jajahannya serta Politik Pembodohan untuk penduduk diwilayah Hindia Belanda pada saat itu,penduduk Indonesia dibagi menjadi 3 golongan penduduk, yaitu Golongan Eropa, Golongan Pribumi, dan Golongan Timur Asing.

\section{Abstract}

Inheritance law is inseparable from the origin of the Indonesian nation which consists of various ethnic or ethnic groups so there are various rules that have been formed related to inheritance law in Indonesia. Population classification and the applicable law for each of these groups are based on the provisions of 163 paragraph (1) IS (Indische staats Regeling 2 inherited from the Dutch East Indies Colonial Government. Supervising the population in the colony and politics of duping for the population in the Dutch East Indies at that time the Indonesia population groups, namely the European Group the Indigenous Group, and the foreign eastern group. 


\section{Jurnal Cakrawala Hukum, Volume 11 No. 1 April 2020}

ISSN PRINT 2356-4962 ISSN ONLINE 2598-6538

\section{Latar Belakang}

Warisan ialah "soal apakah dan bagaimanakah berbagai hak-hak dan kewajiban-kewajiban tentang kekayaan seseorangpada waktu ia meninggal dunia akan beralih kepada orang lain yang masih hidup."(Wirjono, 1976) "aturan-aturan hukum yang mengenai cara bagaimana dari abad ke abad penerusan dan peralihan dari harta kekayaan yang berwujud dan tidak berwujud dari generasi pada generasi. Menurut Supomo "Hukum Adat waris memuat peraturan-peraturan yang mengatur proses meneruskan serta mengoperkan barang-barang harta benda dan barang-barang yang tidak berwujud benda (immateriele gooderen) dari suatu angkatan manusia (generatie) kepada turunannya" (Soepomo, 1976) Menyangkut surat keterangan ahli waris, terlebih dulu yang harus dipahami adalah mengenai pewarisan.

Hukum waris juga tidak terlepas dari asal muasal bangsa Indonesia yang terdiri dari beragam suku atau etnis, sehingga adanya beragam aturan yang telah terbentuk terkait hukum waris di Indonesia. Golongan penduduk serta hukum yang ada guna tiap golongan tersebut didasarkan pada aturan 163 ayat (1) IS (Indische staats Regeling) warisan dari Pemerintah Kolonial Hindia Belanda.

Golongan penduduk serta hukum yang ada untuk tiap golongan penduduk itu ialah Politik Hukum berasal dari pemerintah kolonial guna mengawasi penduduk berada didaerah jajahannya serta juga "Politik Pembodohan" penduduk diwilayah Hindia Belanda saat itu, penduduk Indonesia dibagi 3(tiga) golongan penduduk, antara lain (Simanjutak, 1999):

a). Golongan Eropa, sesuai ketentuan Pasal 163 ayat (2) I.S penduduk yang masuk golongan eropa ialah: 1. Semuanya warga negara Belanda; 2. Semua Orang eropa; 3. Warga negara Jeepang; 4. Orang-orang berasala dari negara lain yang mana hukum kekeluargaan persis hukum keluarga Belanda. 5. Keturunan- keturuan mereka itu, b). Golongan Pribumi, sesuai ketentuan pasala 163 Ayat (3) I.S penduduk yaang masuk golongan pribumi ialah: 1. Orang-orang Indonesia aseli; 2. Mereka yang mula masuk golongan lain, kemudian menjadikan dirinya menjadi orang Indonesia asli. c). Golongan Timur Asing, sesuai ketentuan pasal 163 Ayat (4) I.S, penduduk yang masuk golongan timur Asing adalah mereka yang tak masuk penduduk golongan Eropa ataupun penduduk Indonesia aseli, ialah: 1).Golongan Timur Asing Tionghoa (cina); 2). Golongan Tiimur Asing bukan Tionghoa.

Eksistensi ketentuan pasal 163 I.S sesuai kentuan pasal II atauran peralihan UUD 1945 yang menjelasakan bila "segala badan Negara dan peraturan yang ada masih langsung berlaku, selama belum diadakan yang baru meneurtut Undang Undang Dasar ini" ketentuan pasal II aturan peralihan ini hanya sebagai ketentuan yang mempunyai fungsi yang guna mengisi kekososngan hukum, dengan adanya ketentuan pasal II aturan peralihan, aturan-atuaran hukum berlaku saat zaman penjajahan Belanda masih saja berlaku, sebelum dibuatnya atuaran hukum yang baru. Ketentuan pasal II aturan peralihan disebut juga sebgaia asas konkordansi. (Wahab, 2007)

Undang-undang Dasar Republik Indonesia 1945 yang mana terdapat pada pasal 28D ayat (1), menyebutkan: "setiap orang berhak atas pengakuan, jaminan, perlindungan, dan kepastian hukum yang adil serta perlakuan yang sama dihadapan hukum", ini juga tertuang pada Undang-undang No. 12 tahun 2006 tentang kewarganegaraan yang menganut asas non diskriminasi dan asas persamaan didalam hukum serta pemerintah, Asas non diskriminasi merupakan asas yang tidak membeda bedakan perlakuan dalam segala hal terhadap warga negaranya.

Undang-Undang No. 12 tahun 2006 tentang kewarganegaraan khususnya ketentuan pasa 14 


\section{Penghapusan diskriminasi, ras, dan etnis pembuatan surat keterangan waris yang didasarkan ...}

menjelasakan, pada intinya peduduk hanya dibedakan menjadi dua, yaitu Warga Negra Indonesia (WNI ) dan Orang Asing, dalam hal ini yang masih menjadi patokan untuk pembeda dari golongan penduduk di Indonesia masih terjadi pada ketentuan mengenai pembuatan surat keterangan waris, sebagaiamana dijelaskan dalam pasal 42 ayat (1) PP No. 24 tahun 1997 tentang pendaftaaran tanah juncto aturan psl 111 ayat (1) huruf c "Peraturan Kepala Badan Pertanahan Nasional No. 8 tahun 2012 tentang perubahan Peraturan Menteri Negara Agraria/Kepala Badan Pertanahan Nasional No. 3 Tahun 1977 tentang Pendaftaran Tanah.

Surat tanda bukti sebgai ahli waris yaitu: 1 . Wasiat darii pewaris; 2. Putusan pengadilan; 3. Penetepan hakim atau ketua pengadilan; 4. WNI penduduk asli surat keterangan ahli waris dibuat oleh para ahli waris yang diskasikan oleh 2 orang saksi serta dikuatkan olehh Kepdes atau keluarahan serta camat tempat tinggal pewaris pada waktu meniinggal dunia. Untuk WNI keturunan Tionghoa akta keterangan hak mewaris dari notaris. Untuk WNI keturunan Timur Asing lainnya SKW dari Balai Harta Peninggalan; 5. Surat kuasa tertulis serta ahli waris apabiila yang mengajukan permohona pendaftaran peralihan hak tidak ahli waris yang bersangkutan; 6. Bukti identitas ahlii waris.

Aturan tersebut merupakan aturan wajib yang harus digunakan dalam pembuatan suart tanda bukti sbagai ahli waris yang sebagimana dijelaskan pasal 42 ayat (1) PP No. 24 th1997 tentang pendaftaran tanah dengan kata lain kementrian agrarian dan tata ruang/badan pertanahan nasional sebagai lembaga yang berwenang dalam pelaksanaan kegiatan pendaftaran tanah mengaburkan pembuatan surat keterangan waris dibuat sesuai ketentuan tersebut.

Sebagaimana termuat dalam UndangUndang No. 20 tahun 2004 sebagaimana diubah dengan Undang-Undang No. 2 tahun 2014 Ten- tang Jabatan Notaris (UUJN), yang dalam Pasal 15 mengatur wewenang Notaris. Berdasarkan Pasal 15 ayat (1)UUJN yang mana berbunyi: “ notaris berwenang membuat akta otentik mengenai semua pembuatan, perjanjian dan ketetapan yang diharuskan oleh peraturan perundangundangan dan/atau yang dikehendaki oleh yang berkepentingan untuk dinyatakan dalam akta otentik, menjamin kepastian tanggal pembuatan akta, menyimpan akta, memberi grosse, salinan dan kutipan akta semuanya itu sepanjang pembuatan akta - akta itu tidak juga ditugaskan atau dikecualikan kepada pejabat lain atau orang lain yang ditetapkan oleh undang - undang".

Pasal 15 ayat (1) UUJN guna menegaskan menyangkut jabatan notaris sebagai pejabat umum yg berwennag membikin alat bukti dalam bentuk akta otentik. Pengaturan yang berhubungan mengenai akta otentik yang dibuat oleh pejabat yang berwenang diatur dalam pasal 1868 BW dan pasal 1angka 7 UUJN. Uraian diatas dapat dilihat apabila seharusnya penggolongan penduduk harus dihapuskan khususnya yang mana terjadi pada pembuatan surat keterangan waris adalah terlihat rasis, pada dasarnya konstitusi di Indonesia khusunya yang tertuang pada pasal 28 D ayat (1) Undang-undang Dasar Republik Indonesia 1945 yang pada intinya semua WNI mempunyai kedudukan sama dihadapan hukum tanpa ada kecuali.

\section{Metode}

Metode yang digunakan adalah penelitian hukum normatif dengan pendekatan patung dan pendekatan konseptual. Bahan hukum utama digunakan dalam bentuk undang-undang yang berkaitan dengan Mahkamah Konstitusi, termasuk Undang-Undang Dasar Negara Republik Indonesia Tahun 1945, Undang-Undang Nomor 8 Tahun 2011 tentang Perubahan atas Undang-Undang Nomor 24 Tahun 2003 tentang Mahkamah Konstitusi, Undang-Undang No. 48 tahun 2009 tentang 


\section{Jurnal Cakrawala Hukum, Volume 11 No. 1 April 2020}

ISSN PRINT 2356-4962 ISSN ONLINE 2598-6538

Kekuasaan Kehakiman, Putusan Mahkamah Konstitusi No. 1-2 / PUU-XII / 2014 tentang Dewan Kehormatan Mahkamah Konstitusi (MKMK).

Materi hukum sekunder meliputi teori-teori hukum dari para ahli dalam bentuk buku dan jurnal hukum yang berhubungan dengan konsep dan prinsip keadilan, hakim konstitusi dan sistem pengawasan hakim. Penulisan dimulai dengan penentuan kerangka kerja, penentuan ide, mengumpulkan bahan literatur yang relevan sesuai dengan topik yang diangkat dan mengumpulkan bahan hukum. Kemudian materi yang dikumpulkan ditinjau dan dianalisis untuk dihubungkan ke dalam diskusi penelitian untuk menarik kesimpulan (Marzuki, 2012).

\section{Pembahasan}

\subsection{Pembuatan surat keterangan waris berdasarkan golongan penduduk}

Golongan penduduk diIndonesia tak bisa dipisahkan melalui sejarah bangsa Indonesia pada saat pra kemerdekaan, khususnya berhubungan dengan politik hukum yang fungsinya untuk pedoman pembentukan hukum positif yang pernah serta masih digunakan. Padmo Wahjono menyatakan: "Politik hukum sebagai kebijakan dasar yang menentukan arah, bentuk maupun isi hukum yang akan dibentuk; Politik Hukum adalah kebijakan penyelenggara negara tentang apa yang dijadikan kriteria untuk menghukum sesuatu."

Politik hukum itu dipengaruhi adanya suatu perubahan sistem Pemerintah Belanda sIstem pemerintahan monarki absolut jadi sistem pemerintahan monarki konstitusional yang mana produkk keputusannya Algemene Verordening"/ "Koninklijk Besluit" yang sama diberlakukan di "Neederlands Indie (Hindia Belanda)", politik hukum yang ada pun dipengaruhi oleh fenomena politik yang berkembang serta berubah-ubah. Sesuai dengan perubahan sIstem pemerintahan Belanda melalui sIstem pemerintahan monarki konstitu- sional jadi sIstem pemerintahan monarki konstitusional parlementer, ada perubahan politik hukum yang berpengaruh pada pemerintahan atau peraturan perundang-undangan yang diberlakukan di daerah jajahan Belanda, perubahan tersebut didasarkan pada Pasal 59 ayat I, II, dan IV Grondwet yang juga kemudian disebut juga Regeriings Reglement (RR). Pasal 75 grondwet lalu disebut sebagai Regeriings Reglement (RR), tapi golongan. Penduduk bukan lagi didasarkan pada agama, akan tetapi didasarkan pada "siapa yang menjajah" dan "siapa yang dijajah".

Tahun 1920, grondwet mengalami perubahan, kemudian disebut Regerings Reglement RR (yang baru), dengan demikian juga politik hukum yang digunakan, juga mengalami perubahan, sesuai Pasal 75 RR (yang baru) penggolongan penduduk tak lagi berdasar pada "siapa yang menjajah" serta "siapa yang dijajah" tapi didasarkan pada siapa yang disebut "pendatang" serta siapa yang disebut "yang didatangi".

Dasarnya golongan penduduk dibedakan menjadi 3 (tiga) golongan yaitu, golongan Eropa, golongan Timur Asing, dan golongan Bumi Putra. Dengan begitu pun sebagai akibat dibentuknya vollksraad (wakil rakyat), Regerings Reglemen (RR) dirubah jadi Indische Staatsreheling (IS) sebagai grondwet, yang mulai berlaku saat tanggal 1 Januari 1926. Pasal 131, IS menetapkan politik hukum, yang isinya yang ada pada Pasal 75 RR (baru). Ketentuan itu, kemudian diatur lebih lanjut pada Pasal 163 IS, yang disalin dari ketentuan Pasal 109 RR (baru), Pasal 163 IS yang terdiri dari 6 ayat, akan tetapi yang berkaitan mengenai penggolongan penduduk hanya terdiri dari 4 (empat) ayat.

Pasal 131 IS untuk hukum dasar atau grondwet juga berlaku sebagaii politik hukum yang jadi payung hukum atas berlakunya peraturan perundang-undangan di bawahnya, serta juga akan berlaku dimasa datang, sesuai politik hukum didasarkan kepada ketentuan Pasal 131 IS, terdapat pemberlakuan hukum yang berbeda bagi 


\section{Penghapusan diskriminasi, ras, dan etnis pembuatan surat keterangan waris yang didasarkan ...}

Fadilla Dwi Lailawati

tiap golongan penduduk, dengan adanya Notaris, lembaga Notaris yang sudah dikenali sejak abad ke 17 bersamaan dengan adanya keberadaan "VOC (Verreniigde Oost Ind Compagnie)" di Indonesia, Notaris ditunjuk Jan Pieeterszoon Coen Gubernur Jenderal, guna mencukupi kebutuhan penduduk juga pedagang di Jakarta, pada saat itu Notaris disebut "Notarium Publicum"(Habib, 2008).

Adanya Notaris di Hindia Belanda lalu diberikan batas - batas wewenang serta tugasnya guna membikin akta serta kontrak-kontrak, melalui stablaad itu, Notaris saat melakukan tugas serta wewenanganya tujuan untuk memberikan kepada akta yang dibuatnya kekuatan pembuktian serta pengesahan, menetapkan dan memastikan tanggalnya, menyimpan asli atau minutanya dan mengeluarkan grosse atau salinan yang sah dan benar.

Tidak satupun terdapat di dalam Notariswet ketentuan yang mengatur mengenai pembuatan surat keterangan waris, pembuatan surat keterangan waris selama itu didasarkan pada Pasal 14 ayat 1 dan 3 Grootboeken ner Nationale Schuld, yang dengan asas konkordansi juga diberlakukan di Hindia Belanda. Aturan itu dirasa untuk lex specialis yang khusus jadi dasar pembuatan SKW, yang lau pada system hukum Indonesia paska kemerdekaan diakui serta diterima untuk doktrin serta yurisprudensi sampai lalu dianggap sebagai hukum kebiasaan (Herlien, 2013). Aturan itu jadi dasar pembuatan SKW bagi golongan Timur Asing Cina atau bagai WNI Keturunan Tionghoa. Namun bagi golongan Timur Asing lainnya, jadi pembuatan SKW dibuat oleh Balai Harta Peninggalan Notaris sebagai pejabat umum serta berwenang oleh negara guna membuktikan akta otentik. Namun tanggung jawabnya ialah mempastikan jika akta dibuatnya mempunyai kekuatan pembuktian sempurna, hingga akta yang dibuat mesti sesuai dengan yang ditentukan pada Pasal 1868 KUHPerdata.

Pembuatan SKW didasarkan penggolongan penduduk sudah ada sejak jaman VOC, saat ini didasarkan pada asas konkordansi Pasal 14 Wetopde Grootboeken derNationale Schuld "Undangundang tentang Buku Besar Perutangan Nasional di Belanda", Pasal 14 ayat 2 Ordonnantiie tanggal 22 Juli 1916, Psl 111 ayat 1 huruf c angka 4 PP 24/ 1997 tentang Pendaftaran Tanah, Pasal 42 ayat (1) jo PERMENAG Agraria/Kepala BPN Nomor 3 tahun 1997 tentang Ketentuan Pelaksanaan Peraturan Pemerintah Nomor 24 Tahun 1997. Pembuatan SKW oleh instansi berbeda-beda ialah salah satu konsekuensi akibat masih berlakunya pluralisme sistem hukum waris.

Perspektif bertujuan hukum, jadi politik hukum serta sistem hukum waris yang berlaku berdasar golongan itu, tak bisa dikatakan telah memberikan keadilan hukum, khususnya untuk golongan bumiputera/WNI Penduduk Asli, guna mendapat (SKW) Surat Keterangan Waris yang memenuhi hukum pembuktian. Dalam Hal ini tentu saja bertentangan dengan prinsip negara hukum yang menghendaki akan adanya perlindungan pada HAM khususnya Pasal 28 D Undang-undang Republik Indonesia 1945.

\subsection{Segmentasi golongan penduduk}

Segmentasi berarti pembagian bersegmensegmen, pembelahan diri. Segmentasi Golongan Penduduk adalah pemisahan atau penggolongan penduduk Indonesia berdasarkan etnis dan golongan tertentu (Pius, 1994). Pemisahan penduduk Indonesia yang sesuai etnis serta golongan mencuat setelah penjajahan kolonial Belanda melakukan invansinya keIndonesia. Golongan penduduk Indonesia berdasarkan ketentuan Pasal 163 IS (Indische Staatregeling) yang menggantikan Pasal 109 RR (Regerings Reglement). Penduduk atau rakyat Indonesia dibedakan atau dibagi pada golongan-golongan antara lain: 1. Golongan Indonesia Asli (Bumiputera/Inlander); 2. Golongan Eropa; dan 3. Golongan Timur asing, yang dibedakan lagi dalam timur asing tionghoa serta timur asing lainnya (Komar, 1983). Penggolongan 


\section{Jurnal Cakrawala Hukum, Volume 11 No. 1 April 2020}

ISSN PRINT 2356-4962 ISSN ONLINE 2598-6538

penduduk serta hukum yang ada untuk setiap golongan penduduk itu merupakan politik hukum dari pemerintahan Kolonial Belanda guna mengawasi penduduk yang berada didaerah jajahannya serta dalam upaya pembodohan serta politik memecah belah (devide et impera-politik adu domba) guna penduduk di wilayah Hindia Belanda saat itu.

\subsection{Asas keadilan pada pembuatan surat keterangan waris yang didasarkan penggolongan penduduk}

Nilai-nilai pada Pancasila diyakini kebenarannya oleh bangsa Indonesia sebagai pedoman hidup,dalam sila ke 2 berisi tentang kemanusiaan yang adil dan beradab, sering kali nilai-nilai dalam Pancasila ini diabaikan sebagian orang menganggap apabila yang namanya keadilan adalah kesamaan, semua dibagi sama rata.

Keadilan merupakan nilai kebaikan yang paling utama dalam kehidupan manusia, karena nilai tersebut tidak dapat dipertukarkan (dikompromikan) dengan nilai apapun. Menurut Hans Kelsen, keadilan merupakan cita-cita yang tidak rasional yang mencerminkan reaksi emosional dari individu ataupun golongan terhadap kaidahkaidah hukum positif, karena keadilan tidak pantas menjadi subjek dari kajian falsafati. Terlepas dari perbedaan mengenai hakikat dan makna keadilan, namun tak dapat disangkal bahwa sejak dahulu sampai sekarang umat manusia selalu mendambakan keadilan.

Istilah social justice (Rasuanto, 2005) atau pun keadilan sosial yang diartikan sebagai konsepsikonsepsi umum menyangkut social firmness ataupun keadilan sosial yang mungkin bisa, dan mungkin tak berselisih dengan konsepsi keadilan individu serta keadilan secara umum. Tindakan suatu individu adil ataupun tak adil artinya "legal" atau "illegal", yaitu suatu tindakan itu pas atau tidak dengan normaa hukum yang ada guna menilai seba- gian dari tata hukum positif (Santoso, 2012). Subyek utama keadilan ialah struktur dasar masyarakat, atau lebih tepatnya cara lembaga-lembaga sosial mendistribusikan hak serta kewajiban yang fundamental juga menetukan pembagian keuntungan dan kerja sama sosial.

Keadilan menurut Aristoteles mesti dibagikan oleh negara kepada semua orang serta hukum yang memiliki tugas menjaga supaya keadilan sampai pada semua orang (Sajipto, 2000). Macammacam keadilan dikemukakan oleh Aristoteles, Aristoteles membagi keadilan menjadi tiga golongan, yaitu (Sugianto, 2017): a). Keadilan distributif adalah keadilan pada hal pendistribusian kekayaan ataupun kepemilikan lainnya pada masing-masing anggota masyarakat terdapat keadilan distributif, yang dimaksudkan Aristoteles ialah keseimbangan antar apa yang dapat (he gets) oleh seseorang dengan apa yang patut didapatkan (he deserves); b). Keadilan komulatif adalah perlakuan terhadap seseorang yang tidak melihat jasa yang dilakukannya, yakni setiap orang mendapat haknya; c). Keadilan findikatif adalah perlakuan terhadap seseorang sesuai kelakuannya, yakni sebagai balasan kejahatan yang dilakukan.

Teori tentang keadilan Plato mengemukakan keadilan individual serta keadilan dalam negara. Plato menjelaskan bahwa guna menemukan pengertian yang tepat menyangkut keadilan individual, lebih dulu mesti ditemukan mengenai sifatsifat dasar dari pada keadilan tersebut didalam negara, maka dari itu Plato mengemukakan (Gie, 2002): "let us enquire first what it is the cities, then we will examine it in the single man, looking for the likeness of the larger in the shape of the smaller". Macammacam keadilan menurut teori Plato, yaitu (Bahder, 2002): a). Keadiilan moral ialah keadilan yang terjadi bila mampu untuk memberikan sebuah perlakuan seimbang antara hak serta kewajiban; b). Keadilan prosedural adalah keadilan yang terjadi bila seseorang melaksanakan perbuatan yang sesuai dengan tatacara yang diharapkan. 


\section{Penghapusan diskriminasi, ras, dan etnis pembuatan surat keterangan waris yang didasarkan ...}

Fadilla Dwi Lailawati

Plato dan Aristoteles, mengemukakan keadilan dikaitkan dengan prinsip moral dan masyarakat, yakni kebajikan manusia. Hukum dianggap sebagai kristalisasi nilai-nilai moral dalam masyarakat. Plato percaya bahwa keadilan harus menjadi tujuan negara. Keadilan menjadi jiwa dari pemikiran hukum baik Plato maupun Aristoteles, karena pada masa ini keadilan menempati posisi sentral dalam politik.

Tujuan akhir dan hukum adalah keadilan. Keadilan sangat subjektif dan adanya perbedaan pendapat yang tidak pernah selesai. Hari Chand mengatakan keadilan adalah kata-kata yang sangat samar dan melahirkan arti yang bervariasi, ia mencatat ada banyak variasi penggunaan kata keadilan, ada 9 (sembilan) arti yang digunakan, yaitu:

a). Social Justice, keadilan sosial berhubungan dengan distribusi keuntungan-keuntungan dan beban-beban dalam keseluruhan suatu masyarakat seperti yang dihasilkan lembagalembaga sosial utama, sistem kepemilikan dan organisasi-organisasi publik atau sering disebut dengan keadilan distributif yang mengatur hubungan orang dan benda atau barang; b). Commutative Justice, fokus pada masalahmasalah transaksi-transaksi privat, memerlukan pertukaran sepadan, berupa ganti rugi yang sepadan, terkait hubungan antar benda; c). Substantive Justice, menunjukkan pada materi dari persoalan-persoalan diliputi dalam suatu sengketa/perselisihan; d). Procedural Justice, menunjukkan penerapan-penerapan prosedur dalam penyelesaian suatu sengketa ataupun dalam pengambilan suatu keputusan; e). Corrective Justice, memperlihatkan untuk memugar kembali keseimbangan etika terganggu oleh tingkah laku yang salah; f). Comparative and Non Comparative Justice, Ia mengemukakan pendapat Feinberg memisahkan antara keadilan komparatif yang meliputi perbandingan antara orang-orang yang bervariasi, pembatasan orangorang adil/pantas hanya dengan mengacu pada hubungan-hubungannya dengan orang- orang lain dan keadilan yang tidak komparatif dimana seseorang adil/pantas didefinisikan secara independen dari yang lainnya; g). Global Justice, keadilan yang tidak akan berubah dari tempat ketempat dan sedikitnya sama meliputi seluruh dunia adalah keadilan global atau universal; h). Particular Justice, adalah yang berlawanan dengan global justice, keadilan particular yang ruang lingkupnya sempit, seperti dibatasi pada suatu desa atau masyarakat. Keadilan dalam suatu bagian masyarakat mungkin digambarkan sebagai ketidakadilan belaka oleh yang lain, kalau dilihat dari sudut pandang mereka; i). Legal Justice, adalah keadilan menurut hukum dan keadilan yang dilakukan atau menurut takaran sebagai hasil dari penerapan hukum, adalah mungkin menjadi suatu kasus bahwa hukum dalam persoalan adalah tidak adil.

Achmad Ali menyebutkan apabila hukum hanya semata-mata guna untuk mewujudkan keadilan, karena bagaimanapun nilai keadilan mesti subjektif serta abstrak. Beberapa pendapat tentang keadilan, maka keadilan merupakan sesuatu yang abstrak dan bersifat subjektif yang identik dengan konsep hukum dan sesuai dengan nilai yang dianut oleh individu serta masyarakat.

Sementara itu, Jeremy Bentham dan kaum utilitarian menafsirkan keadilan sebagai kesetaraan. Apabila ada kepentingan dua orang saling berbenturan yang benar adalah berdasarkan manakah di antara dua orang itu yang akan menikmatinya atau bagaimanakah kebahagian itu dibagi di antara mereka. Keadilan dalam pandangan “ John Rawls " dikenal dengan keadilan sosial, dalam pandangannya keadilan dikatakan sebagai faiirness terkandung asas-asas, jika orang-orang yang merdeka serta rasional mempunyai kemauan guna mengembangkan kepentingannya,mestinya mendapat syarat yang fundamental untuk mereka guna masuk pada perhimpunan yang mereka hendaki. 


\section{Jurnal Cakrawala Hukum, Volume 11 No. 1 April 2020}

ISSN PRINT 2356-4962 ISSN ONLINE 2598-6538

Ada 2 (dua) tujuan dari teori keadilan John Rawls, yang Pertama ialah tiap orang punya hak yang sama mengenai kebebasan dasar paling luas, seluas kebebasan yang sama untuk semua orang. Kedua, ketimpangan sosial serta ekonomi harus diatur sedemikian rupa maka bisa diharapkan memberi keuntungan bagi setiap orang serta semua posisi juga jabatan terbuka untuk tiap orang (Rawls, 2011).

Berkaitan dengan asas keadilan pada Pembuatan SKW didasarkan pada Golongan Penduduk pada Undang-undang No. 40 Tahun 2008 tentang Penghapusan Diskriminasi Ras dan Etnik Diskriminasi, khususnya diskriminasi etnis yang dikenal pada saat zaman kolonial, yaitu saat berlakukannya berbagai produk kebijakan yang sifatnya diskriminatif, sama diberlakukannya mengenai Catatan Sipil untuk Golongan Eropa, tentang Catatan Sipil guna Golongan Timur Tionghoa, tentang Catatan Sipil untuk Golongan Indonesia Asli beragama Kristen.

Pemberlakuan Pasal 163 IS, tak terkecuali pada pembuatan SKW. Ketentuan itu berlaku atas dasar politik hukum "devide et impera"/"politik memecah belah", antara golongan pribumi serta golongan timur asing Tionghoa (hesti, 2013). Diskriminasi, sesuai Pasal 1 angka 1 Undangundang No. 40 tahun 2008, diskriminasi ialah suatu bentuk pembedaan, pengecualian, pembatasan, ataupun pemilihan yang didsarkan sesuai ras serta etnis, yang menyebabkan pencabutan serta pengurangan pengakuan, perolehan, atau pelaksanaan HAM dan kebebasan atas dasar suatu kesetaraan pada bidang sipil, politik, ekonomi, sosial, dan budaya.

Undang-undang No. 40 Tahun 2008 mengenal dua macam diskriminasi, yakni diskriminasi Ras dan diskriminasi etnik. Ras menurut Pasal 1 angka 2 Undang-undang No. 40 Tahun 2008 ialah golongan bangsa berdasarkan ciri-ciri fisik serta garis keturunan, pengertian ini tak jauh berbeda dengan Ras sesuaai KBBI, yang diartikan golongan bangsa menyangkut ciri-ciri fisik; rumpun bangsa.
Etnis mengenai suatu istilah mempunaai arti yang lebih luas, karena etnis juga dapat digolongkan sesuai ras.

Ommen pendapatnya ada beragam - ragam atribut yang menggambarkan kelompok etnis, yaitu: agama, sekte, kasta, daerah, bahasa, nasionalisme, keturunan, ras, warna kulit serta kebudayaan. Etnis menurut Undang-undang No. 40 Tahun 2008 ialah penggolongan manusia berdasarkan kepercayaan, nilai, kebiasaan, adat istiadat, norma bahasa, sejarah, geografis, dan hubungan kekerabatan. Kedua istilah tersebut cukup erat korelasinya dengan fenomena penggolongan penduduk yang telah terjadi sejak zaman penjajahan Belanda sebagaimana dijelaskan sebelumnya, Hesti di dalam bukunya "Diskriminasi Rasial dalam Hukum HAM Studi Tentang Diskriminasi Terhadap Etnis Tionghoa", menegaskan bahwa bentuk penggolongan penduduk tersebut merupakan bentuk diskriminasi rasial. Hal ini bertentangan dengan Pasal 4 Bab III tentang Tindakan Diskriminatif, Undang-undang No. 40 Tahun 2008 tentang Penghapusan Diskriminatif Ras dan Etnis, yaitu: memperlakukan pembedaan, pengecualian, pembatasan, ataupun pemilihan berdasarkan sesuai ras serta etnis, yang mengakibatkan pencabutan atau pengurangan pengakuan, perolehan, atau pelaksanaan hak asasi manusia dan kebebasan dasar dalam suatu kesetaraan di bidang sipil, politik, ekonomi, sosial, dan budaya;

Praktek memperlakukan berbeda untuk setiap golongan penduduk tertentu pada pembuatan SKW yang ada pada Pasal 163 IS, hal ini merupakan tindakan yang mengakibatkan pelanggran HAM serta kebebasan mendasar pada hak asasi bagi semua penduduk Indonesia guna mendapat alat bukti sempurna pada hukum perdata khususnya untuk alat bukti atas hak waris, tak terkecuali bagi golongan pribumi juga golongan timur asing kecuali Tiong Hoa, yang selama ini dibikin dibawah tangan atau dibuat oleh pejabat atau instansi yang tak sesuai.

Persamaan pada hukum (Equaliity before the law); penegakan hukum dengan cara tak berten- 


\section{Penghapusan diskriminasi, ras, dan etnis pembuatan surat keterangan waris yang didasarkan ...}

Fadilla Dwi Lailawati

tangan dengan hukum "Due Process of law". Notaris sebagai jabatan profesional, sangat memungkinkan melakukan suatu kesalahan gunaa menjalankan jabatan. Kesalahan yang disebabkan oleh Notaris saat melaksanakan jabatannya bias menyebabkan kerugian bagi clien karena akta kekuatan pembuktianya terdegradasi jadi akta dibawah tangan, atau akta jadi batal demi hukum, hingga karena kesalahannya itu, seorang Notaris bisa dituntut di muka pengadilan baik karena wanprestasi atau karena perbuatan melanggar hukum.

Dalam hal ini apabila dikaji dengan teori keadilan dirasa pemerintah kurang adil dalam membuat peraturan ini karena pada dasarnya setiap warga negara haruslah punya kedudukan yang sama dihadapan hukum yang mana dituangkan dalam Undang-undang dasar Republik Indonesia 1945 yang setara terdapat pada pasal 28 D ayat (1), menyatakan: "setiap orang berhak atas pengakuan, jaminan, perlindungan, dan kepastian hukum yang adil serta perlakuan yang sama dihadapan hukum ".

\section{Simpulan}

Pembuatan SKW didasrkan pada penggolongan penduduk sudah ada saat jaman VOC, dasarnya asas konkordansi Pasal 14 "Wet opde Grootboeken der Nationale Schuld" (Undang-Uundang tentang Buku Besar Perutangan Nasional di Belanda). Golongan penduduk serta hukum yang ada untuk setiap golongan penduduk itu ialah politik hukum dari pada pemerintahan Kolonial Belanda guna mengawasi penduduk yang ada didaerah jajahannya dan suatu upaya pembodohan dan politik memecah belah "devide et iimpera"politik adu domba) guna penduduk di wilayah Hindia Belanda pada waktu itu.

Berdasarkan politik hukum yang didasarkan pada ketentuan didasarkan pada ketentuan 163 ayat (1) IS (Indische staats Regeling) warisan dari Pemerintah Kolonial Hindia Belanda, yang mana maka terdapat pemberlakuan hukum yang berbeda bagi setiap golongan penduduk,yang mana kemudian oleh pemerintah dituangkan juga pada Peraturan Kepala Badan Pertanahan Nasional No. 8 tahun 2012 tentang perubahan Peraturan Menteri Negara Agraria/Kepala Badan Pertanahan Nasional No. 3 tahun 1997 tentang pedaftaran Tanah, dan saat ini masih digunakan menjadi hukum positif.

\section{Daftar pustaka}

Adjie, Habib. 2008. Hukum Notaris Indonesia Tafsir Tematik Terhadap UU No. 30 Tahun 2004 Tentang Jabatan Notaris. Bandung. Refika Aditama.

Budiono, Herlien. 2013. Kumpulan Tulisan Hukum Perdata di Bidang Kenotariatan. Buku Kedua. Bandung. Citra Aditya Bakti.

Gie, The Liang. 2002. Teori-Teori Keadilan. Yogyakarta. Sumber Sukses.

Logo Tadu, O. (2017). Perlindungan hukum terhadap anak luar kawin dalam pembagian waris adat Toraja. Jurnal Cakrawala Hukum, 8(1), 96-105. doi:10.26905/idjch.v8i1.1735.

Meta, K. (2017). Kedudukan waris anak angkat menurut hukum waris adat Bali. Jurnal Cakrawala Hukum, 19(1), 39-48. doi:10.26905/idjch.v19i1.1129.

Nasution, Bahder Johan. 2002. Kajian Filosofis Tentang Hukum dan Keadilan dari Pemikiran Klasik Sampai Pemikiran Modern. Jambi. Fakultas Hukum Universitas Jambi.

Prodjodikoro, Wirjono. 1976. Hukum Waris di Indonesia. Bandung. Cetakan ke-11.

Rahmita, N., \& Budiono, R. (2017). Analisis kompilasi hukum islam tentang tolok ukur hibah yang diperhitungkan sebagai warisan. Jurnal Cakrawala Hukum, 8(1), 75-85. doi:10.26905/idjch.v8i1.1733.

Rasuanto, Bur. 2005. Keadilan Sosial Pandangan Deontologis Rawls dan Habermas Dua Teori Filsafat Politik Modern. Jakarta. Gramedia Pustaka Utama.

Rawls, John A. 2011. Theory of Justice Teori Keadilan DasarDasar Filsafat Politik untuk Mewujudkan Kesejahteraan Sosial dalam Negara. Yogyakarta. Pustaka Pelajar Offset.

Soepomo. 1967. Bab-Bab Tentang Hukum Adat. Jakarta. Intermasa. 